\title{
Geodynamic Framework of Saline Systems in Eastern Tunisia: Saline Depressions Inherited from the Triassic Intrusions and/or the Messinian Salinity Crisis
}

\author{
Elhoucine Essefi, ${ }^{1,2}$ Jamel Touir, ${ }^{3,4}$ Mohamed Ali Tagorti, ${ }^{5}$ and Chokri Yaich ${ }^{1,2}$ \\ ${ }^{1}$ National Engineering School of Sfax, University of Sfax, Sfax, Tunisia \\ ${ }^{2} R U$ : Sedimentary Dynamics and Environment (DSE) (Code 03/UR/10-03), National Engineering School of Sfax, \\ University of Sfax, Sfax, Tunisia \\ ${ }^{3}$ Laboratory of Water Energy and Environment, National Engineering School of Sfax, University of Sfax, Sfax, Tunisia \\ ${ }^{4}$ Faculty of Sciences of Sfax, University of Sfax, Road of Soukra, km 4, 3038 Sfax, Tunisia \\ ${ }^{5}$ Higher Institute of Biotechnology of Monastir, Tahar Haddad Avenue, University of Monastir, \\ Road Salem Bechir, BP n56, 5000 Monastir, Tunisia \\ Correspondence should be addressed to Elhoucine Essefi; hocinsefi@yahoo.fr
}

Received 12 October 2013; Accepted 24 December 2013; Published 24 April 2014

Academic Editors: A. Förster and T. N. Singh

Copyright (c) 2014 Elhoucine Essefi et al. This is an open access article distributed under the Creative Commons Attribution License, which permits unrestricted use, distribution, and reproduction in any medium, provided the original work is properly cited.

\begin{abstract}
Based on the geodynamic context, two hypotheses of origin of salt in the subsurface of the Sahel area are worth being defended. The first suggests that the halokinesis activities, namely, of the Triassic evaporitic sedimentation, may still be until now influencing the functioning of the saline systems in the Sahel. The second integrates the Sahel area geodynamic evolution in the framework of the convergence between African and Eurasian plates. It suggests a link between the blockage of the subduction between African and Eurasian plates in North Tunisia, the Messinian Salinity Crisis, and eventually the concrete opening and evolution of the playa during the Quaternary. Such a suggestion is materialized by a geodynamic model relating successively these events. This scenario suggests that the Messinian Salinity Crisis constituted huge quantities of salt and/or salty water. This saline subsurface reserve is until now influencing the Sahel behavior as a whole. Through groundwater convergence, huge quantities of salt are accumulated within depressions of the Sahel area. Currently, the convergence of the plate between African and Eurasian plates results in a tectonic activity within these saline systems materialized by the formation of fault spring mounds along preferential orientation ensuring the surface-subsurface connectivity.
\end{abstract}

\section{Introduction}

Though structures of the previous tectonic activities in the Sahel area are covered by a thick Plio-Quaternary series, geological and geophysical studies (e.g., [1-7]) gave a lot of data on the deep tectonic structures and the salt tectonics that was enhanced by the intrusion of the Triassic domes [3, 4]. The geodynamic inheritance in the subsurface of this region is still until now controlling the geology of its surface. For instance, the genesis and evolution of saline depressions in the Tunisian Sahel were strongly controlled by its subsurface, which controlled their formation and evolution [1] and is still until now feeding them with huge quantities of salt through aquifers convergence toward their surfaces [8-11]. The aim in this paper is to examine the geodynamic context that controlled the genesis and evolution of saline systems in Tunisian Sahel such as the Mechertate-Chrita-Sidi El Hani system, not only during the geomorphologic shaping and real opening of their depressions but also during previous geological events that had provided a salty context to the subsurface of the Sahel area. This work aims also to study geochemical traces of this salty geodynamics, which may be detected in aquifers. Based on these geochemical and geodynamic studies, this paper discussed two hypotheses of the origin of 


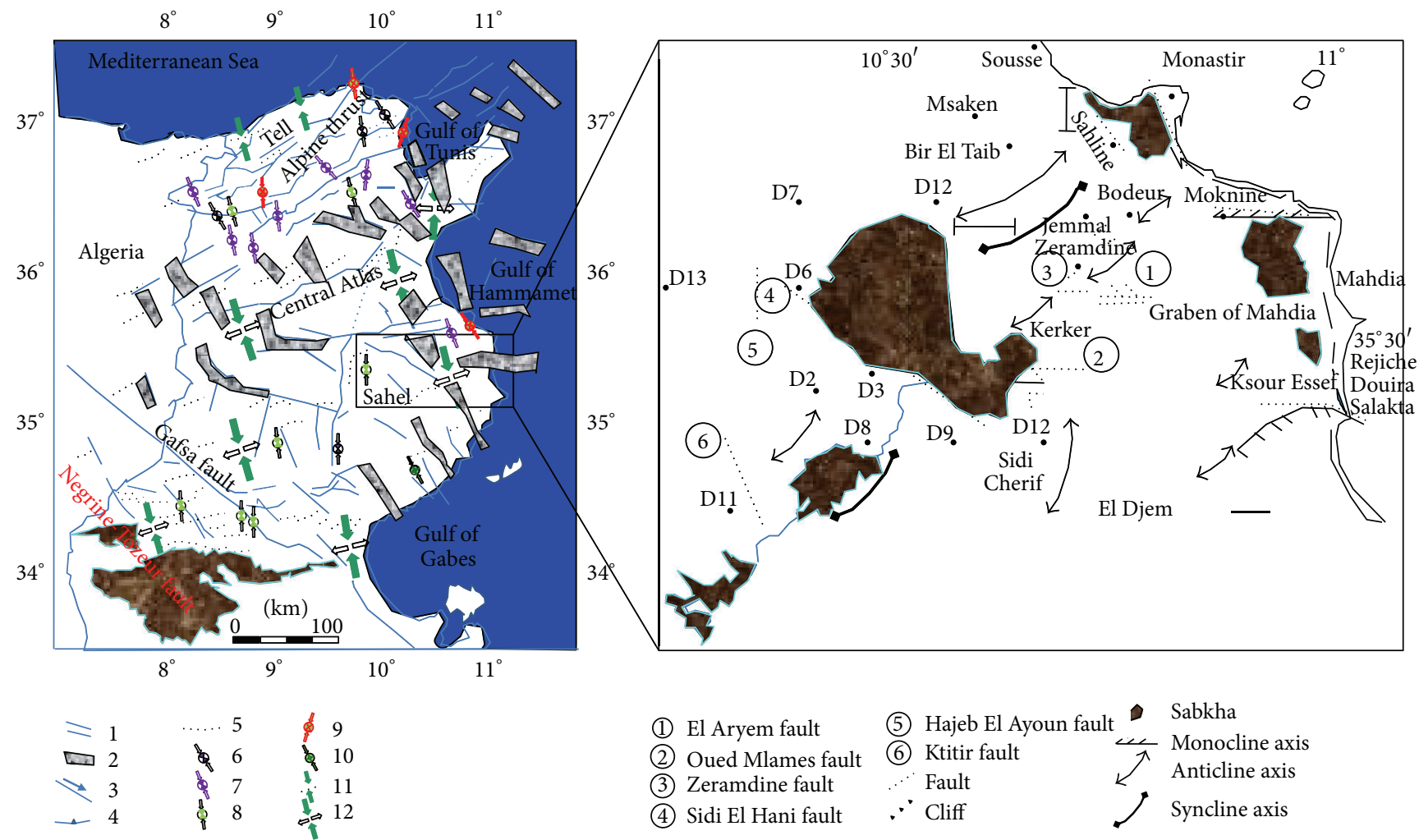

(a)

(b)

FIGURE 1: (a) Recent and current tectonic and seismotectonic map ([41], modified; [7]): 1: principal faults with Plio-Quaternary rejuvenation or presenting seismic activity indices, 2: graben with Plio-Quaternary rejuvenation, 3: strike-slip fault, 4: overthrust, 5: Quaternary fold or Quaternary rejuvenation, 6: direction of the $P$ axis of seismic focal mechanism, 7: direction of the $P$ axis of composite focal mechanism, 8: direction of compression based on the surface deformations of recent seisms (microtectonic data), 9: direction of compression based on the historical tectonic deformations (microtectonic data), 10: direction of the maximum horizontal constraint (in situ measurements), and 11: direction of surface principal stresses with indication of their positive $(\sigma 1)$ and negative $(\sigma 3)$ values [7]. (b) Tectonic map of MechertateChrita-Sidi El Hani system: sites of seismic and geologic sections and locations of the hydrogeological drills [6].

salt in the subsurface of the Sahel area. The first suggests that the halokinesis activities, namely, of the Triassic evaporitic sedimentation and its intrusion by an Eocene compression $[3,4]$, may be still until now influencing the functioning of the system. The second integrates the geodynamic evolution of the Sahel area in the framework of the convergence between African and Eurasian plates [12]. It suggests a link between the blockage of the subduction between African and Eurasian plates in North Tunisia [12], the Messinian Salinity Crisis, and eventually the concrete opening and evolution of the playa during the Quaternary [1]. Such a suggestion is materialized by a geodynamic model relating successively these events. In doing so, this study proves the existence of a Triassic and/or Messinian salty context in the subsurface of the Sahel area that may feed depressions with salt, especially in the case of aquifers convergence. A special care was given to the Mechertate-Chrita-Sidi El Hani system where groundwater convergence [10, 11], salt accumulation [11], salinization [13], and hydrocarbons migration [14] have been verified.

\section{Geologic Settings of Mechertate-Chrita-Sidi El Hani System}

The system is located in the northern part of the Tunisian Sahel. This zone is characterized by NE-SW platforms reduced to hills landscape (Figure 1(a)). These topographic surfaces represent anticlines with big radiuses and small slopes (several degrees). The littoral plains of Mahdia and Jemmal take place within collapsed zones with a syncline character or a graben form. The laters were cut by saline depressions along NW-SE orientations.

As it is the case for the Northern Sahel, the MechertateChrita-Sidi El Hani system is separated by numerous bulges coinciding with N045 hills and platform. These slightly developed reliefs are represented by plied structures, which constitute the southern continuity of Central Atlas folds. Within the Mechertate-Chrita-Sidi El Hani system, from north southward, we distinguish the anticlines of Bodeur, Bir El Taieb, El Aryem-Menzel Hayet, El Guessaat, and Ktitir (Figure 1(b)). To the major NW-SW orientation, we observed 
in the south the N-S running anticline of Sidi Cherif. Most of the anticlines are separated by synclines. For instance, the syncline of Jemmal separates the anticlines of Bir El Taieb and Zeramdine [6].

The Mechertate-Chrita-Sidi El Hani system is cut by a faults network controlling the Mio-Plio-Quaternary deposition within subsiding zones such as the synclines of Jemmal and Chorbane and orienting the hydrographic network (Figure 1(b)). These faults, which are inherited from the Cenozoic and Mesozoic [6], show NW-SE and NNE-SSW to E-W orientations. Within the Mechertate-Chrita-Sidi El Hani system, we distinguish several tectonic accidents. The faults series of Zeramdine-Jemmal affected the anticline of Zeramdine; they are N040 and N090 to N120 cartographic accidents. The NE-SW Zeramdine fault stretches to tens of kilometers. The N120 faults network of Sidi Bou Goubrine affected the Menzel Hayet plateau [33]. We find also the faults of Oued Mlames [6] and Sidi El Hani [2, 15].

The weak topographic contrast [16] allowed the setting of huge extended depressions. Within the Mechertate-ChritaSidi El Hani system, the submeridian (NNW-SSE) depressions of Mechertate, Chrita, and Sidi El Hani followed a NWSE preferential lengthening caused by a tectonic control. Sidi El Hani discharge playa and Chrita saline lake are fed by NE-SW with E-W hydrographic network. The Mechertate depression represents a bypass zone within the system. It feeds Chrita and Sidi El Hani depressions.

The hydrogeologic context of the system is complex due to the interference between hydrologic and hydrogeologic networks $[8-10,17,18]$. Though they are two different factors, effects of hydrology and hydrogeology are hardly distinguished in the case of Mechertate-Chrita-Sidi El Hani system because the limit between the surface and subsurface water is not always quite evident. As a concrete example from Sidi El Hani discharge playa, the permanent hydrological network toward the discharge playa, Oued Chrita, is fed by the hydrogeology. This convergence feeds the discharge playa with huge quantities of salt, which are far from being originated from the hydrological watershed. The MechertateChrita-Sidi El Hani system is hence controlled by somewhere deep domes of salt and/or salty water. The convergence of water toward the watershed of the system is materialized by a groundwater influence on the aeolian wet sedimentation [13]. The convergence of water toward the discharge playa of Sidi El Hani and Chrita saline lakes is materialized by the appearance of springs and spring mounds in many locations [19-21].

\section{Methods}

Added to field investigations and data acquisition, the work was mainly based on a cross reinterpretation of data of some previous works such as seismic sections carried out in the Sahel $[1-4,22]$ and a geodynamic model of the convergence and the shift from subduction to collision between African and Eurasian plates from the Miocene to Quaternary discussed by Chihi and Philip [12].

As for the seismic data, added to a seismic section showing the Triassic intrusions in the Tunisian Sahel area
(Figure 1(b); T3), another seismic section (Figure 1(b); M2) served to infer the occurrence of the Messinian Salinity Crisis. It gives a north-south seismic section of Sidi Alouane-Sousse. Actually, this section was first used by Khomsi et al. [4] to study the Eocene tectonics. In this study, the reinterpretation deals with the unconformity of the Messinian Salinity Crisis in the Tunisian Sahel area. Ten drills (Figure 1(b)) recuperated from the Ministry of Agriculture (Tunisia) were also useful to see the variation of the deposition during the Messinian Salinity Crisis and to study the synsedimentary faults of Ktitir and Hajeb El Ayoun. The convergence of surrounding aquifers toward depressions was recently proven by hydrogeological [10] and geochemical [11, 14] studies. Analyses of water of ten drills recuperated from data of the Ministry of Agriculture were taken to endure a geochemical study. First, the use of Piper diagram was meant to study the geochemical facies of samples. Second, the use of SchoellerBerkaloff diagram was meant to prove relation between drills in order to understand if depressions of the system are fed by homogenous or different aquifers. Added to the geochemical facies, Piper diagram gives the possibility to know the correlation between samples. In view of its importance in the interpretation of deep water, Piper diagrams are the most used. They have made up by two ternary plots, representing anions and cations concentrations, which were projected onto a diamond to represent the major ions. They have the advantage of representing many samples and following the geochemical evolution of water. On Schoeller-Berkaloff diagram, samples are presented by broken lines. Samples having the same relative composition are detected even with different concentrations. Thus, samples having genetic relationship are presented by parallel lines. The line shape, hence, is characteristic of a geochemical facies. This representation is useful for spatial comparison. Samples belonging to the same aquifer have the same shapes.

Concerning the geodynamic model, since Chihi and Philip [12] have integrated the Sahel geodynamic evolution in the context of plates, it seems better to interpret Amari and Bedir's [1] geodynamics in the framework of Chihi and Philip's [12] convergence between African and Eurasian plates. Thus, the post-Villafranchian compression is interpreted as a result of the collision between African and Eurasian plates and the migration of the compression toward the Sahel. On the other hand, the Tyrrhenian extension is interpreted as a result of dextral compensation of the compressional constraint. Furthermore, this collision caused the Messinian Salinity Crisis, which may be the origin of the salty water within aquifers of Mechertate-Chrita-Sidi El Hani system and the origin of salt within its depressions.

\section{Results and Discussion}

4.1. Triassic Intrusions as a Source of Salt and a Motivator for Tectonic Activities. The Triassic intrusions in the Sahel area were the subject of previous old studies (e.g., [2]). They were recently discussed based on seismic $[3,4]$ and gravimetric [5] data. Their formation probably started since the Eocene compression [3]. These salty materials had, and 


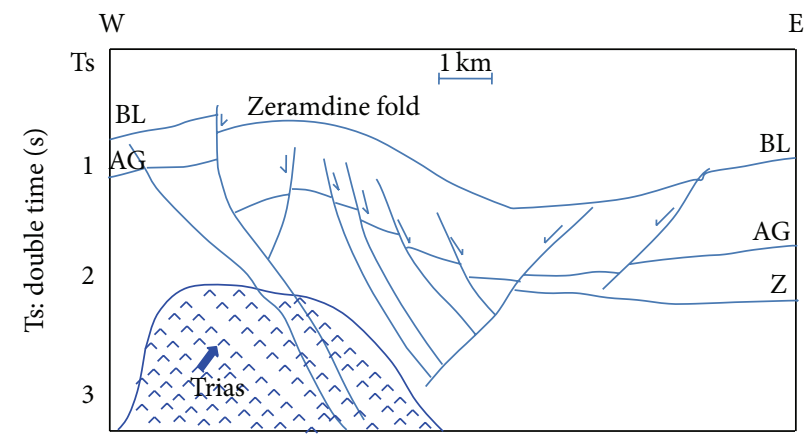

Figure 2: Seismic line T3 showing the Triassic intrusions in the Zeramdine fold [2]: the salty and fractured Triassic subsurface as a possible origin of salt.

have, taken a major role in the geodynamics of the Sahel area. Tectonically, these materials facilitated the tectonic activities that had caused the opening of playas in the Sahel area such as the post-Villafranchian compression and the Tyrrhenian extension. Hydrogeologically, they could feed playas with huge quantities of salt, especially in the case of the convergence of surrounding aquifers towards these playas. Thus, the huge quantities of salt in Tunisian saline systems such as the Sidi El Hani discharge playa, Chrita saline lake, and Elghorra playa could be the result of leaching of Triassic domes. In this vein, Amari and Bedir [1] found a correlation between the tectonic fracturing and the aquifer level and salinity in Moknine, Tunisian Sahel area. This means that the more the zone is fractured, the more the salty material is integrated by leaching the evaporitic domes. Figure 2 shows a dome of salt in Zeramdine just nearby Sidi El Hani discharge playa $(5 \mathrm{Km})$. This figure shows also that the geodynamic context was presented by a fractured zone, which is responsible for the leaching of the Triassic dome and the transport of the salty water.

4.2. Convergence between the African and the Eurasian Plates as a Cause of the Messinian Salinity Crisis and the Opening and Evolution of Playas in the Tunisian Sahel Area. By examining the literature on global, regional, and local contexts of the Sahel area, this study was able to find a causal link between the convergence between African and Eurasian plates [12], the Messinian Salinity Crisis [6,23], and the opening and evolution of playas during the Quaternary [1]. This deduction may be summarized in a geodynamic model relating these interrelated events.

4.2.1. Convergence between African and Eurasian Plates. The convergence from the early and middle Miocene to the Quaternary between African and Eurasian plates [12] should by rights have commanded the geodynamic history of the Sahel area. Chronologically speaking, this convergence may be divided into three phases: subduction-subduction (before the early Miocene), subduction-collision (the TortonianMessinian to Quaternary), and collision-collision (after the Quaternary). During the subduction-subduction phase, the subduction prevailed between African and Eurasian plates at the levels of North Tunisia and Sicily. During the subductioncollision phase, the subduction that prevailed in the early and middle Miocene between African and Eurasian plates in North Tunisia was blocked in the late Miocene (TortonianMessinian) and the zone entered in a collision phase [12]. This collision might have caused the Messinian Salinity Crisis (MSC) [23]. Furthermore, it might have been the cause of the post-Villafranchian NW-SE compression [6] responsible for the opening and evolution of playas in the Sahel area discussed by Amari and Bedir [1]. Because the compressive constraint reached the Tunisian interior lands, namely, the Sahel area. This very same compressional constraint was compensated by dextral compressive thrust faults. These extensional structures and later the Tyrrhenian NE-SW extension discussed by Amari and Bedir [1] may be enhanced by the subduction that was still acting at the level of Sicily. During the collision-collision phase, both sides witnessed collision. The collision at the level of Sicily might have caused the stopping of the Tyrrhenian extension.

4.2.2. Collision between African and Eurasian Plates and the Messinian Salinity Crisis in the Tunisian Sahel Area. Since the discovery of Messinian evaporites in the subsurface of the Mediterranean Sea (e.g., [24, 25]), numerous works and scenarios were devoted to understand the Messinian Salinity Crisis (MSC) (e.g., [26, 27]). Paleomagnetic and astrochronologic studies indicate that the Messinian Salinity Crisis developed between circa 5.94-5.96 and 5.32 Ma (e.g., [28]). Chronologically, this event, thus, coincides with the beginning of the collision between African and Eurasian plates in North Tunisia [12], where the connection between the Mediterranean Sea and the Atlantic Ocean at the level of Gibraltar might be closed, causing, hence, the desiccation of the Mediterranean Sea (e.g., [23]).

(a) The Messinian Salinity Crisis: A Global Event in the Mediterranean Sea. This major and sudden regression related to a desiccation of the Mediterranean is characterized by deep evaporites, associated with a major erosional surface affecting the Messinian sediment. This erosional surface was identified through seismic profiles in offshore areas such as Golf De Lion, France (e.g., [29]). Onshore, the erosional surface in the 


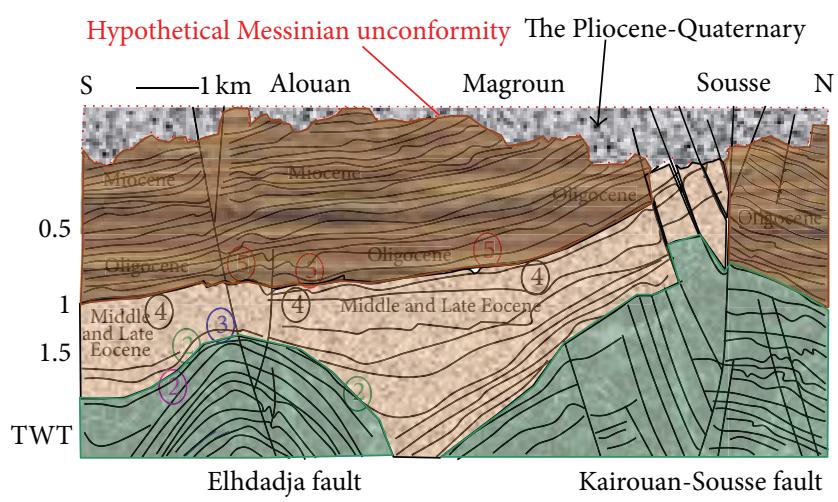

FIgURE 3: Seismic section (M2) showing the detection of the Messinian Salinity Crisis in the Tunisian Sahel area ([4]; reinterpreted).

Rhone (France) was related to deep canyons filled in with the early Pliocene sediments (e.g., Clauzon, 1982). A rapid marine reflooding (Zanclean transgression), hence, is assumed to have occurred during the early Pliocene. Concerning the occurrence of the MSC in the Tunisian Sahel area, since this major event had affected all the Mediterranean costs, the Messinian Salinity Crisis should by rights have a correlative registering in both sides of the Mediterranean Sea (e.g., [30]), including the Sahel area. Before MSC, the Mediterranean Sea was somewhere nearby Kairouan. Thus, the global event is in this zone more likely characterized by sedimentary deposits. The hard task lies in the detection of the strong proof of the MSC in the Sahel area materialized by its erosional surface.

(b) Proofs of the Messinian Salinity Crisis in the Tunisian Sahel Area. As for the detection of erosional surface, this study dealt with data that were not basically meant to investigate the MSC [4]. The seismic section of Khomsi et al. [4] (Figure 3) may represent a proof of the occurrence of the MSC in the Sahel area. It is a N-S seismic section (Figure 1, M2) from Alouan (Sidi Alouan) to Sousse. It was first meant by Khomsi et al. [4] to investigate the Eocene tectonics. But it seems that an erosional surface appears, which may be related to MSC, and it may be the Messinian unconformity. As for the Zanclean transgression that followed the MSC (e.g., [30]), the interpretation of this seismic section cannot go further because it is not known if these sections are of high resolution or not. Nevertheless, the Zanclean transgression is detected in some location in the Sahel area [30].

The marine Pliocene was also discussed by [6] in the Sahel area. Figure 4 shows the succession of the Neogene sedimentation of the Sahel area (Figure 4; D13). The marine Miocene Marl to carbonate is followed by a continental gravelly sedimentation. This continental Mio-Pliocene deposition interrupted by three marl bands coincides with the Segui Formation [7]. However, the absence of this reflooding in many locations in Sahel area may be explained by the uplands of the post-Villafranchian compression [1], which forbade the Mediterranean Sea to return to its initial position in Kairouan neighborhoods. (c) The Messinian Salinity Crisis in the Tunisian Sahel Area as Cause of the Salty Context in Mechertate-Chrita-Sidi El Hani System. In this study, working on the MSC is not a purpose per se. But if the MSC had actually a salty heritage in the Tunisian Sahel area, another possibility of origin of salt and/or salty water is added to the possibility of the Triassic intrusions in the subsurface of the Sahel area. This second possibility is not in contradiction to the possibility of the Triassic intrusions, but it may introduce confusion. The remaining question is still whether it is tolerated to speak about "the Messinian domes" in the Sahel area or not. As a matter of fact, the MSC was associated with the deposition of evaporitic domes in the Mediterranean Sea. But no study has proven something like "the Messinian domes" in the Tunisian Sahel area. Thus, the MSC may be associated in the Sahel (if we suppose at all it had taken place) with a salty context that would be leached and transported toward the playa by the surrounding aquifers. In this study, the presence of the MSC is also inferred just on the basis of its erosional surface. This surface in the Sahel area may prove the event per se, but it does not prove the existence of the evaporitic Messinian domes, which may be inferred from the analogous contexts in the Mediterranean Sea. It is worth noting that if El-Euch-El-Kondi et al. [31] were able to speak about the Messinian evaporites at the level of Chaabet Etabbala in North Tunisia, Sghari and Mercier [30] were not able to give the name "evaporitic domes" to the few levels of secondary gypsum found at the top of the Segui Formation in the Sahel area. Accordingly, until now, there are no concrete proofs of the Messinian domes in the Tunisian Sahel area. Thus, it seems safer to speak about a salty context rather than about domes. The MSC, then, is more likely to let huge quantities of salty water be trapped between high lands of that time.

4.2.3. Recent and Neotectonics in the Tunisian Eastern Coast and the Genesis of Playas in the Sahel Area as Result of Plates Convergence. The recent neotectonic history of the Sahel area is characterized by the succession of many tectonic events [32]. This tectonics is the result of the collisional geodynamics between the African and Eurasian plates with nearing velocity of 0.5 to $1 \mathrm{~cm}$ per year. The calendar of tectonic activities 


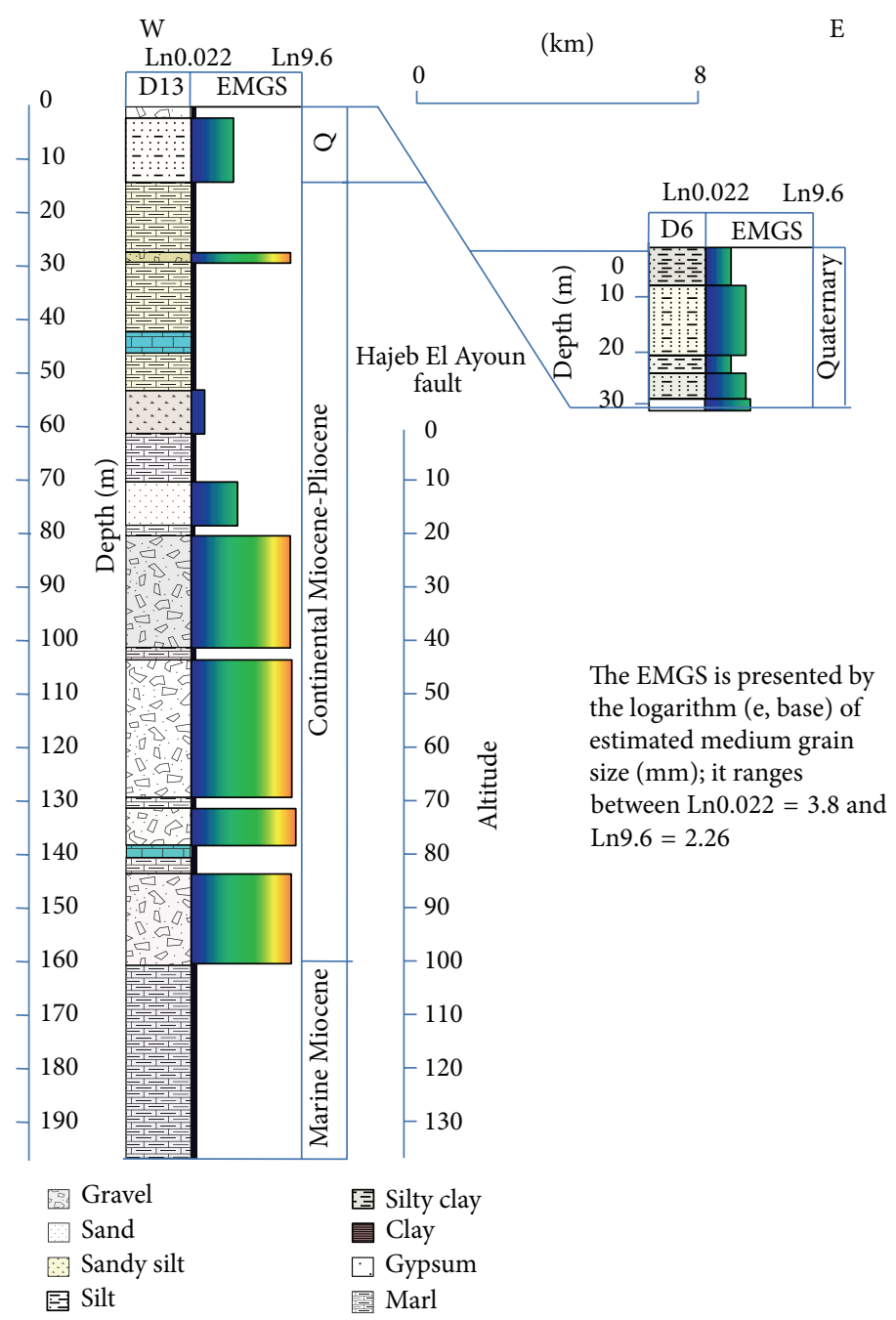

FIGURE 4: E-W correlation between two hydrogeologic drills showing the synsedimentary fault of Hajeb El Ayoun.

was recently published by Ghribi [6]. It encompasses the period ranging from the Tortonian to the present. During the late Tortonian, the so-called NW-SE Atlasic compression dominated the Sahel area. This compression reactivated inversely the population of N100-N130 normal faults, which had been generated by a N045 extension. Then, during the Messinian, a constraints relaxation gave birth to NESW synsedimentary faults (Figures 1, 4, and 5). They were responsible for the individualization of kilometric extension basins. The subsidence of these basins was reinforced by the normal NW-SE accidents. For instance, Hajeb El Ayoun fault (Figure 4) is responsible for the subsidence of the PlioQuaternary series in the vicinity of Sidi El Hani discharge playa. It controlled the subsidence of this depression and enhanced water seepage toward the surface of this depression along numerous springs of water, which was noticed by many authors $[6,8,9,16]$.

On the other hand, Ktitir fault (Figure 5) is responsible for the subsidence of the Plio-Quaternary series in the vicinity of Chrita saline lake. The Messinian structures have been the receptacle of the thick azoic detritic series of the Segui Formation. Subsequently, the extension extended during the Pliocene and deepened grabens already edified during previous events. Such structures commanded the marine Pliocene deposition. During the early Pleistocene, the socalled post-Villafranchian compression reactivated inversely and in thrust faults previous accidents. During the late Pleistocene and Holocene, the NW-SE compression persisted to affect the Tyrrhenian marine deposit and gypsum crust. Currently, the Sahel witnessed a NW-SW to NNW-SSE compression (Figure 1(a)) [7]. Researchers once believed that the genesis and evolution of the coastal lagoons and sabkhas of the Tunisian eastern coast were controlled by two successive Quaternary tectonic phases. A post-Villafranchian NW-SE compression was followed by a Tyrrhenian NE-SW extension [1]. As it is mentioned, these two tectonic events could by no means be excluded from their global geodynamic context cinematically commanded by the convergence between Eurasian and African plates. It is worth stressing that the MCSH system recorded extensional as well as compressional 


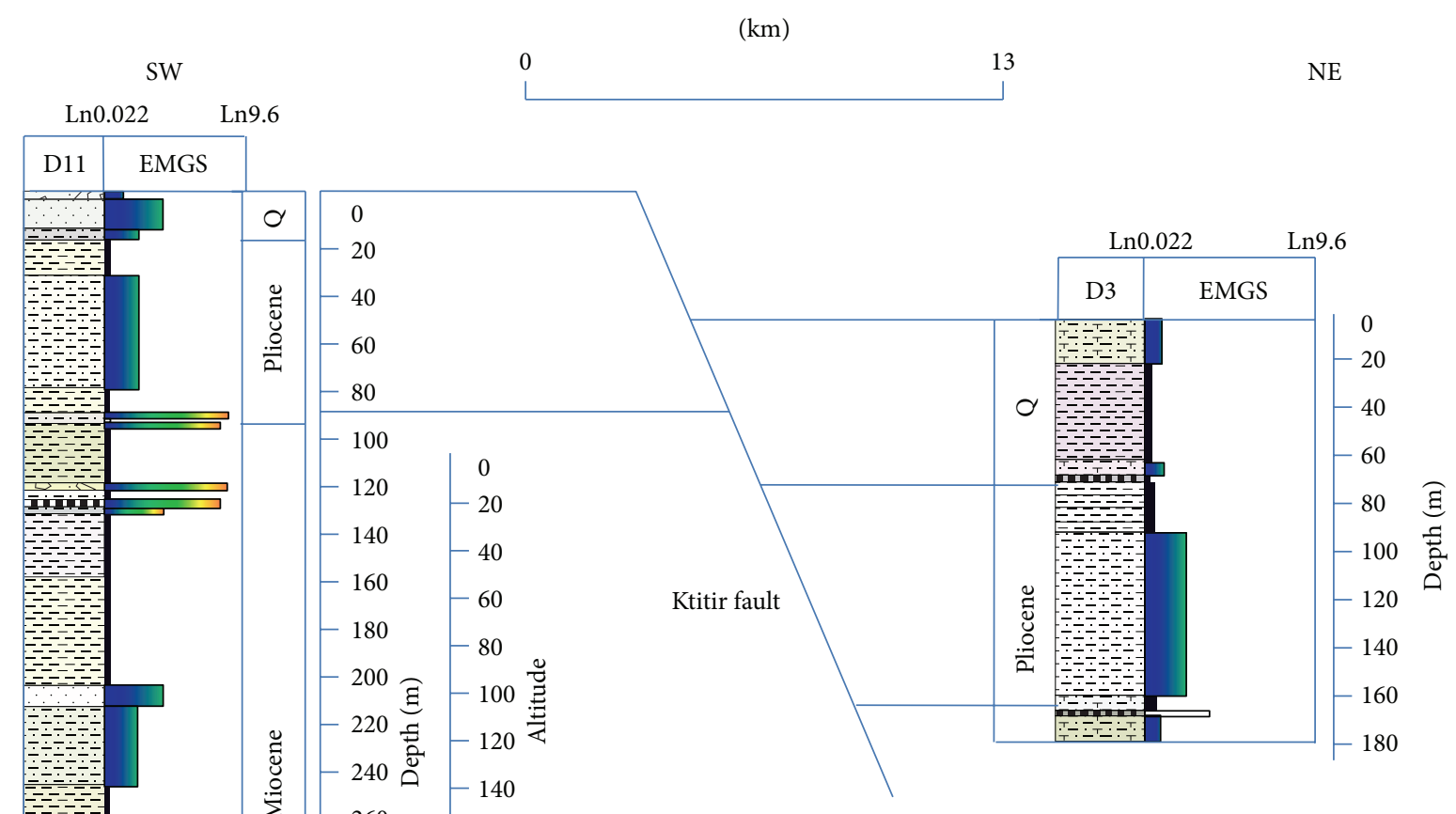

The EMGS is presented by the logarithm (e, base) of estimated medium grain size $(\mathrm{mm})$; it ranges between $\operatorname{Ln} 0.022=3.8$ and $\operatorname{Ln} 9.6=2.26$

tectonic structures. This coexistence has been explained by a succession of two tectonic phases in the Sahel area [1]: a postVillafranchian NW-SE compression followed by a Tyrrhenian NE-SW extension controlled the opening and evolution of playas in the region. However, recent studies (Rekhiss, 2007; [8]) suggested that compressional and extensional structures were coeval and originated from the very same compressional phase, which originated from the AfricanEurasian convergence. Thus, the system experienced a coeval formation of compressional and extensional structures (e.g., $[1,2,4,7,15,22,33-36]$; Hfaiedh, 1983) giving birth to a folded and faulted surface and subsurface.

Figure 6 shows that fracturing is rising in various places of Sidi El Hani watershed [1]. The N90 direction corresponds to the northern and southern limits of Sidi El Hani, Souassi, and Dkhila playas. The N170 direction coincides with the eastern limits of the playas. In addition, the Villafranchian calcareous crust observed in edges of the present playas folds is also cut out into N 00-20 and N 90-110 rhombuses fractures with a set of dextral and senestral setbacks. It is worth noting that similar microtectonic indices have been also found on smaller scale in the Sahel area [1]. These tectonic fractures resulted from the juxtaposition of the compressive and extensional structures during the post-Villafranchian compression and transpressional Tyrrhenian structures (Figure 7).

The post-Villafranchian phase is characterized by NE to EW folds, which were associated with EW compressive thrust faults. These tectonic structures are due to a NWSE compression. The coastal lagoon of Monastir and the playas of Kelibia, Sidi El Hani, Chrita, and Moknine are localized in synclinal gutters or in anticlinal structures of the ploughed up post-Villafranchian phase. This compression 


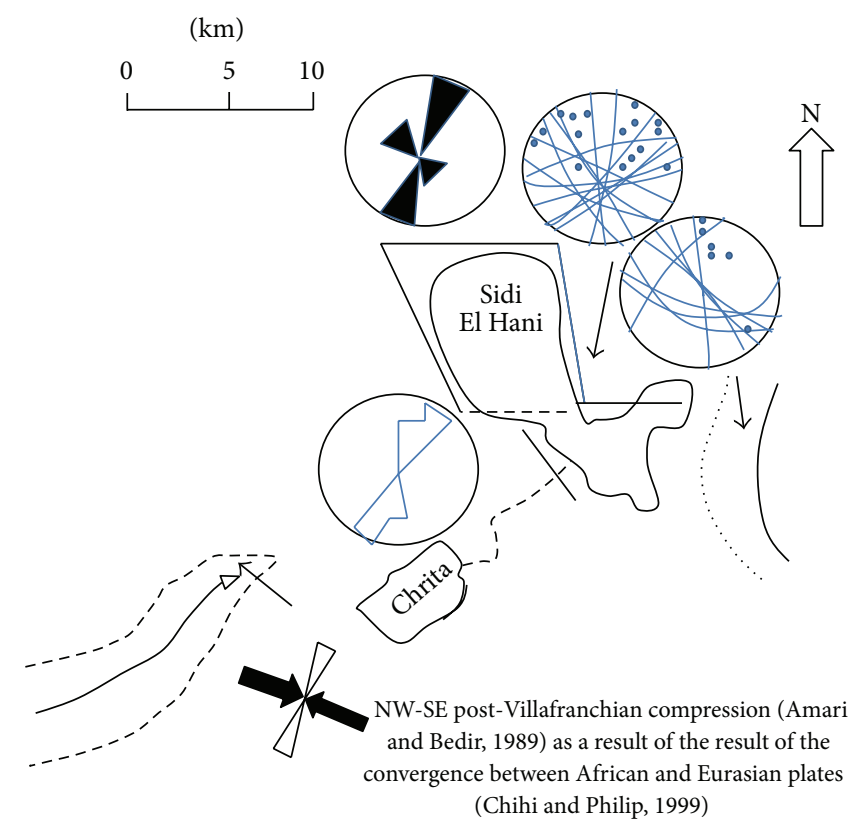

Figure 6: Fracturing of Chrita and Sidi El Hani playas ([1]; reinterpreted).

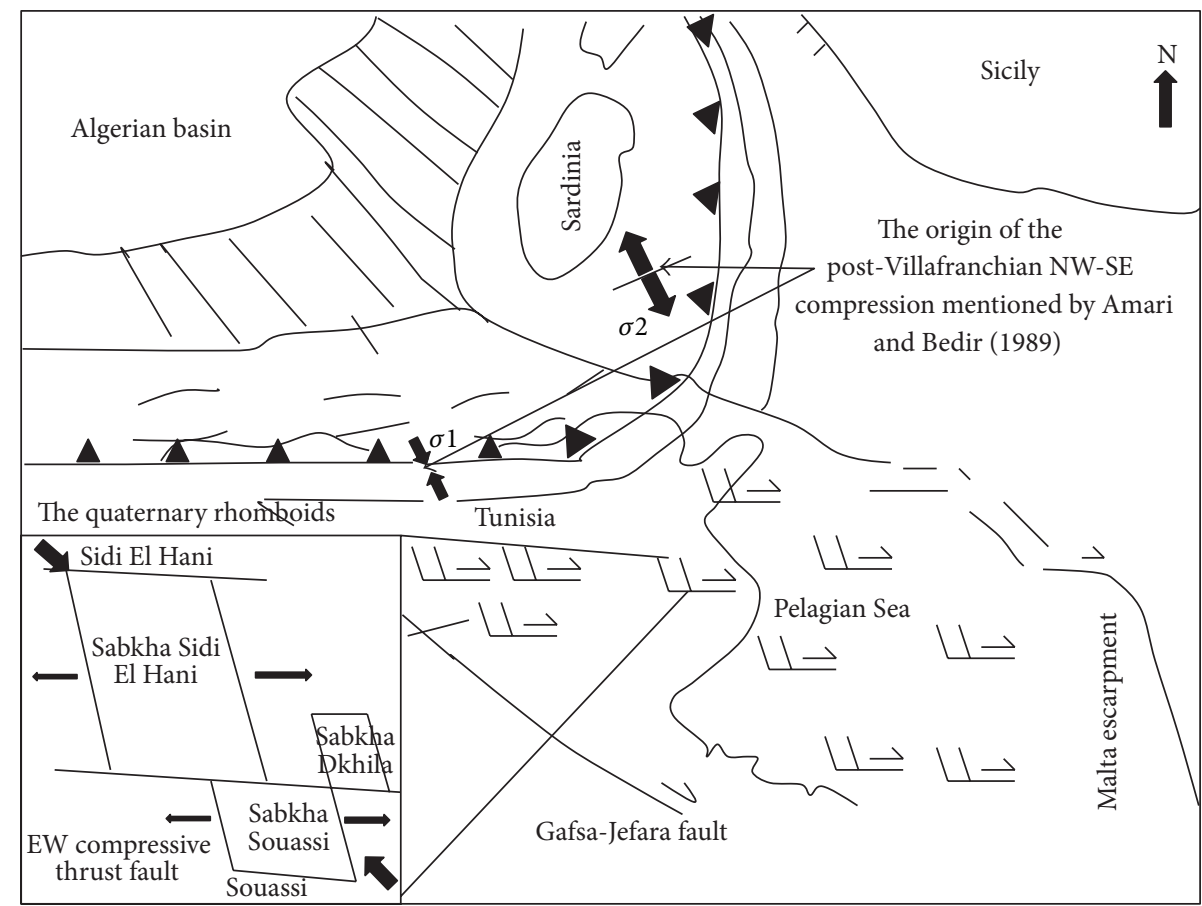

Figure 7: Migration of the compression during the Pliocene and the Quaternary toward the Sahel area and the opening of playas ([12]; modified; [1]; cross-reinterpreted).

had migrated from North to South Tunisia after the blockage of the subduction between Eurasian and African plates in North Tunisia causing, hence, folds and playas opening by compressive thrust faults in the Sahel. This strange juxtaposition of compressive and extensional structures was noticed in Tunisia by [12], namely, with the West to East migration of the blockage of subduction from North Tunisia to Sicily.
During the Tyrrhenian tectonics, a NE-SW extensional phase has combined NS extensional senestral and EW dextral strike-slip faulting. This tectonics reactivated the old faults and caused a cutting of the synclinal basins into decakilometric parallelograms (pull-apart basins). In particular, Sidi El Hani playa is installed on the zone of complex tectonic node, which is located around the Boumerdes tectonic corner 


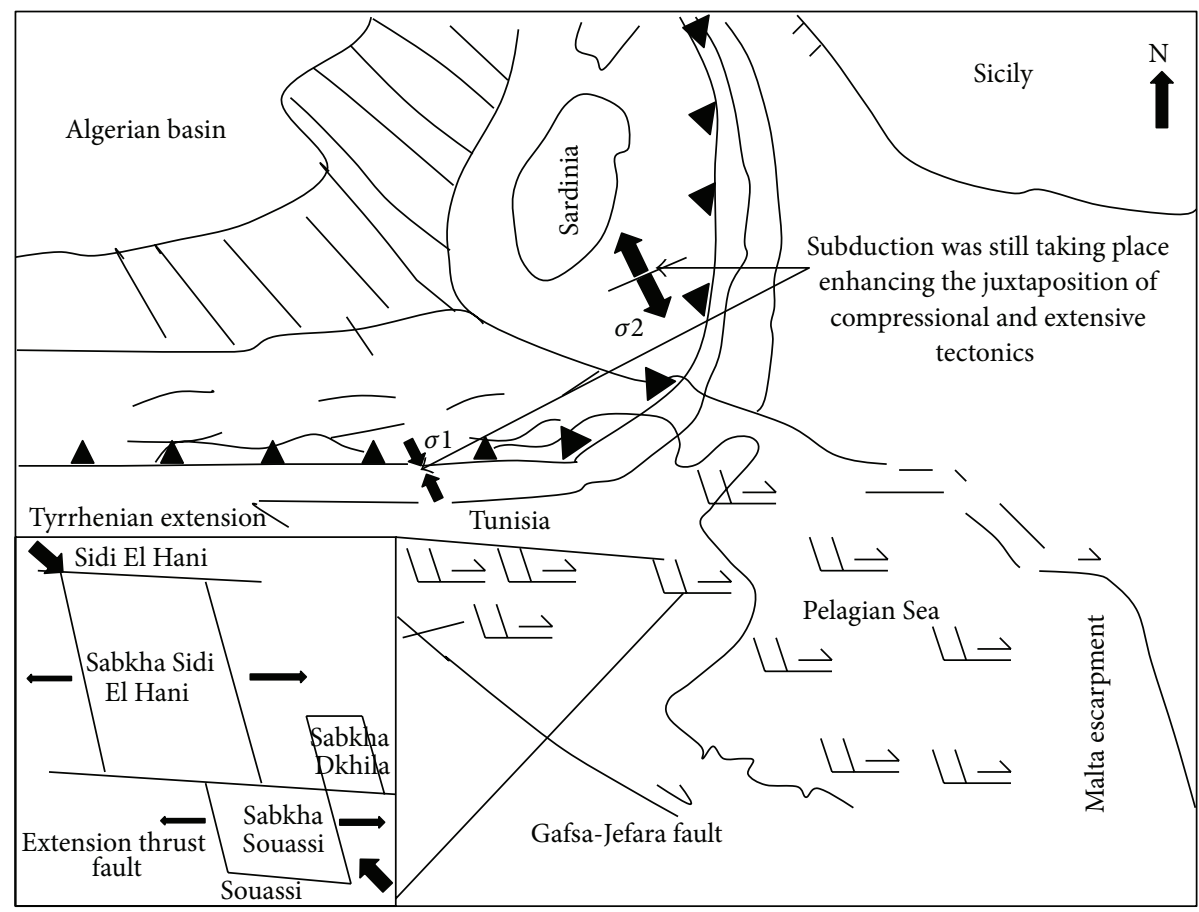

FIgURE 8: Convergence between African and Eurasian plates and The Tyrrhenian NE-SW extension in the Tunisian Sahel area: the playas evolution ([12] (modified); [1]; cross-reinterpreted).

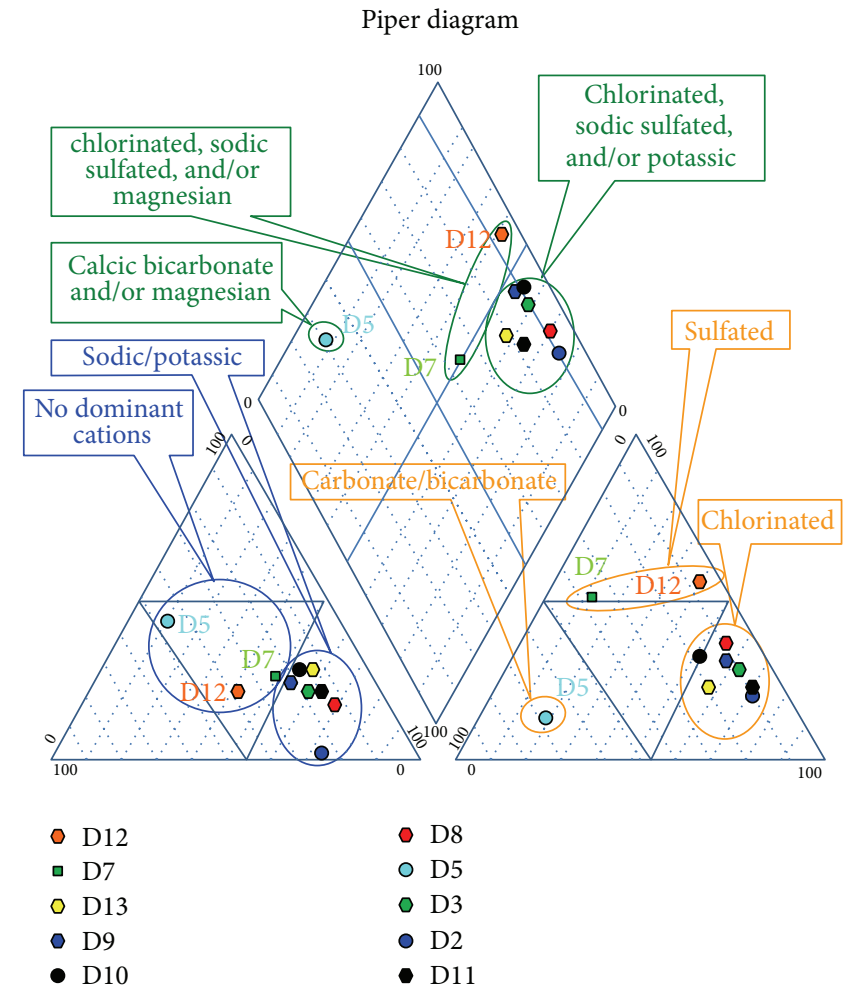

Figure 9: Piper diagram of some drills from the system of Mechertate-Chrita-Sidi El Hani. 


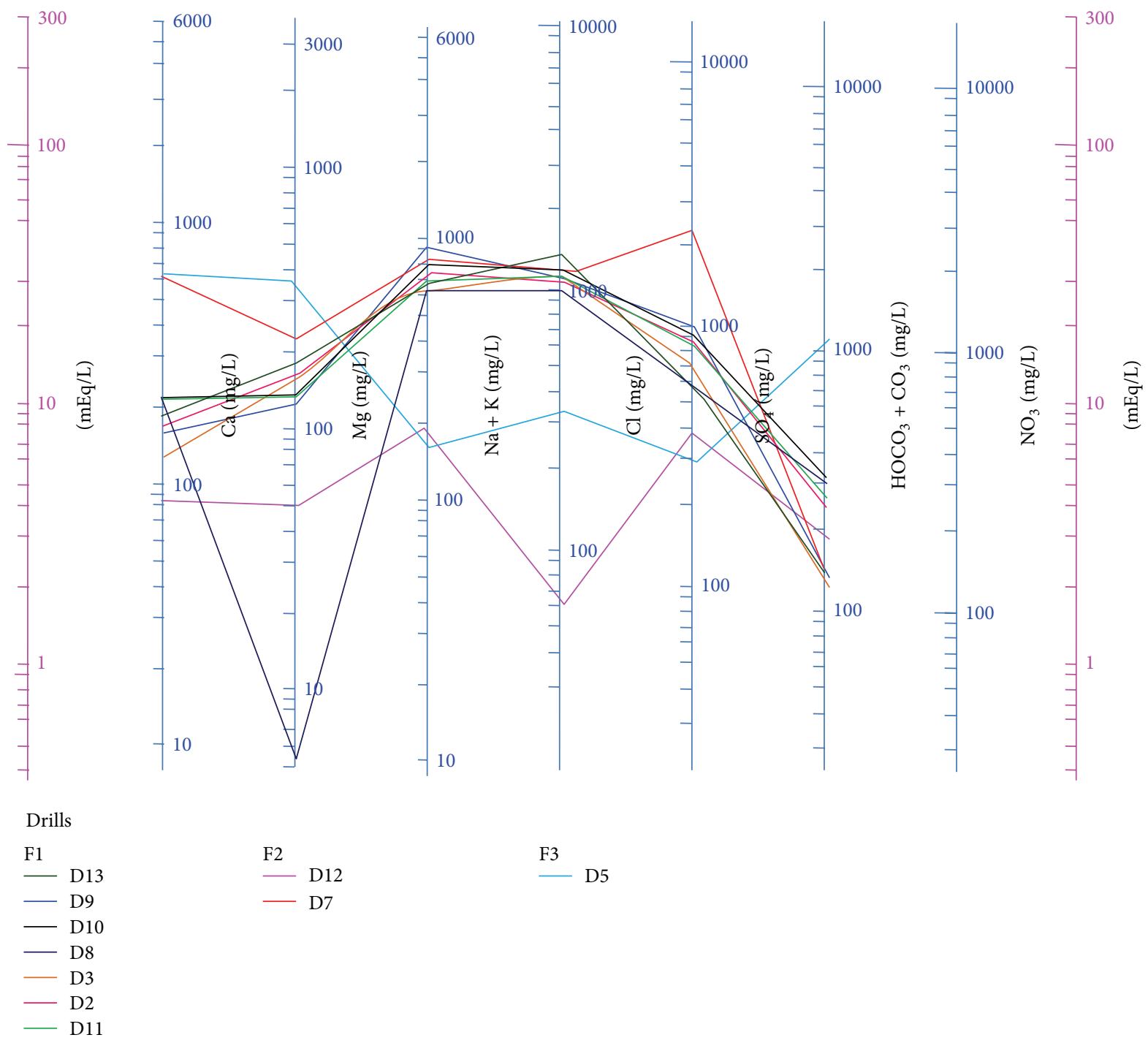

FIGURE 10: The Schoeller-Berkaloff diagram of some drills from Mechertate-Chrita-Sidi El Hani system.

where it was located the tectonic corridor of the faulted folds known as the line of Bodeur-Zeramdine-Chorbane-Bouthadi and the western termination of the Mahdia graben. Actually, at this stage, the subduction was still taking place in Sicily. It compensated the convergence between Eurasian and African plates (Figure 8). In doing so, it reactivated the old EW faults and simplified the juxtaposed activities into one Tyrrhenian extension.

4.3. Geochemical Investigation of Aquifers of MechertateChrita-Sidi El Hani System. Concerning Piper diagram (Figure 9), the interpretation of the dispersion of different samples within the diamond of anions and cations, the diagram of anions, and the diagram of cations may give an idea of the geochemical facies. On the diamond, three families of samples are distinguished. First, the majority of samples make up the chlorinated, sodic sulphated, and/or Potassic family (F1). Second, samples D12 and D7 represent the chlorinated, sodic sulphated, and/or magnesian family (F2). Third, the sample
D5 represents the calcic bicarbonate and/or magnesian family (F3). On the diagram of anions, the families are further made clear. The F1 is chlorinated with the dominance of $\mathrm{Cl}^{-}$. The F2 is sulfated with the dominance of $\mathrm{SO}_{4}^{--}$. The $\mathrm{F} 3$ is carbonated with the dominance of $\mathrm{CO}^{--}$(from crude data). On the diagram of cations, only two families are distinguished. The F1 is classified as sodic/potassic. The F2 and F3 are classified as having no dominant cations. In general, the majority of drills have the same facies (F1), which is mainly made up of water charged with $\mathrm{Na}^{+}$and $\mathrm{Cl}^{-}$. This geochemical facies suggests that this aquifer is more likely leaching domes of halite (the Triassic and/or Messinian) or is made up of salty paleowater probably inherited from the Messinian Salinity Crisis. These findings reinforce the economic importance of Sidi El Hani saline environment discussed by Tagorti [37]. Moreover, this salina may tolerate other industrial saltpans exploiting its huge quantities of alkaline salt. Nevertheless, the geochemistry of F2 may be explained by looking back to the geodynamic context. D12 and D7 are located near the Triassic 


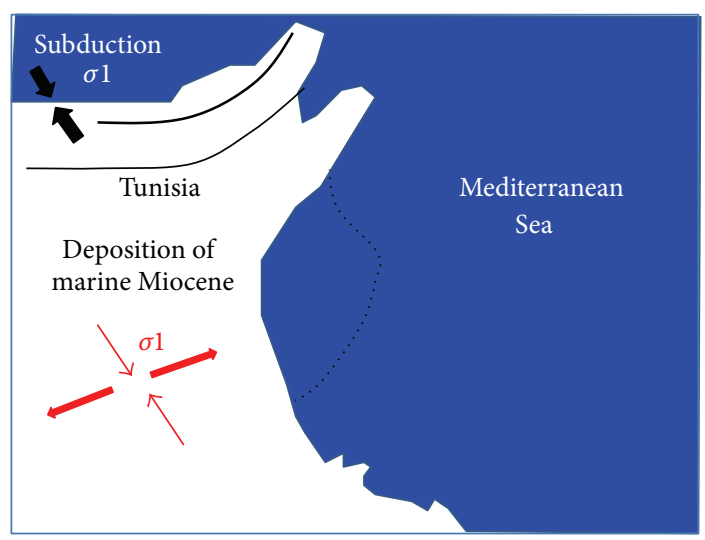

(a) Before the Messinian Salinity Crisis. Tectonically, subduction between African and Eurasian plates had been taking place. The Sahel was evaded by the Mediterranean Sea with deposition of the marine Miocene

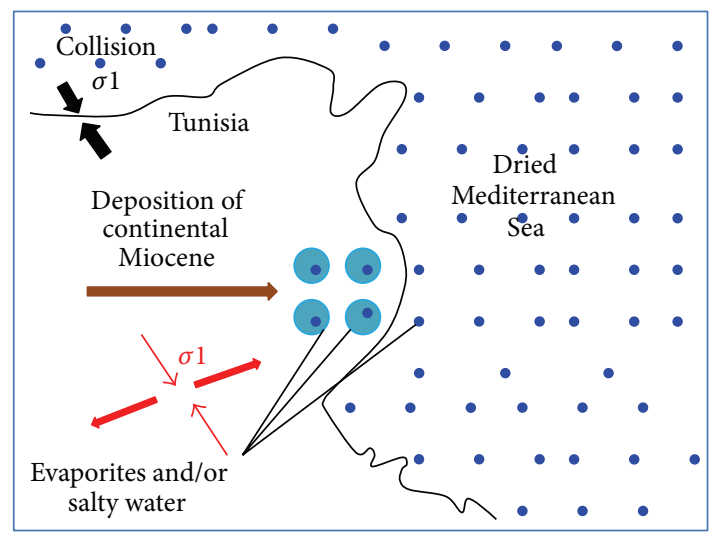

(b) During the Messinian Salinity Crisis. Tectonically, collision started causing the MSC with the stagnation of evaporites and within the dried Mediterranean Sea and the deposition of the continental /or salty water

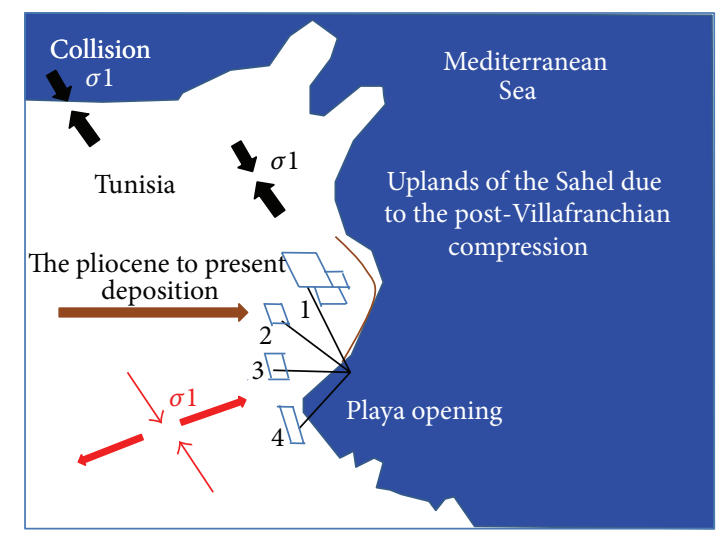

(c) After the Messinian Salinity Crisis. Tectonically, the transposed compression in the Sahel gave birth to folds and playas opening. Even after the MSC, uplands and folds forbad the sea to return to its initial position. The compression has controlled the evolution within playas, especially the formation of faultspring mounds $(1,2,3,4)$

FIGURE 11: Geodynamic model of an inherited playa from the Messinian Salinity Crisis integrated in the framework of the transition from subduction to collision between Eurasian and African plates.

dome in the subsurface of Zeramdine. On the other hand, the geochemistry of F3 could not be explained at this stage, but it may be said that there is somewhere a carbonated layer in the subsurface of this location.

In Schoeller-Berkaloff diagram, similarity between samples generally appears inspite of the different concentrations. Thus, samples having genetic relationship are presented by parallel lines. As for the studied samples, they present for the most part an evident similarity (Figure 10). Families previously distinguished are also seen in this diagram. The F1 is characterized by high value of $\mathrm{Na}^{+}$and $\mathrm{Cl}^{-}$. The F2 is characterised by high values of $\mathrm{SO}^{--}$. The $\mathrm{F} 3$ is characterised by high value of $\mathrm{CO}^{--}$. Thus, we are in face of three different aquifers.

4.4. Geodynamic Model of Inherited Saline Systems. The history of saline systems started before the geomorphologic shaping of the Sahel and the real opening of its depressions during the Quaternary. Though the Trias and the Messinian preceded their real genesis, their effect on their behavior proves vital. The Triassic intrusions in the Sahel area of Tunisia have been discussed by many authors in Tunisia [2-4]. Their effect on the salinization of water resources has always been inferred (e.g., [1]). On the other hand, the Messinian, namely, its salinity crisis, has never been integrated in this context. This study proposes its own scenario for inherited saline systems from the Messinian (Figure 11). This scenario suggests that the Messinian Salinity Crisis has left behind it huge quantities of salt and/or salty water, which are until now influencing the systems behavior as a whole. The depressions of the saline system are influenced by this inheritance by huge quantities of salt accumulated especially in Sidi El Hani discharge playa. This inheritance makes these depressions controlled by endogenous factors rather than exogenous ones such as the climatic variability [8-10]. At the level of the watershed of the system, this inheritance is 
materialized by capillary fringe, which outcrops in the eolian sand. After its evaporation, this water precipitates quantities of evaporates integrated within sediment of watershed [13, 16]. It is worth noting that this hypothesis has nothing contradictory to the hypothesis of the Triassic intrusions; hence, they may be both true. This model of convergence between the two plates is until now (human and geologic scales) influencing the tectonic activity. On the geologic scale, tectonic subsidence during the last two millennia is quite different within the eastern Tunisian sabkhas. During the last millennia, tectonic subsidence decreases from north to south with the sedimentation of $114 \mathrm{~cm}, 104 \mathrm{~cm}$, and $65 \mathrm{~cm}$ within sabkha Souassi [13], Dkhila [13], and Mhabeul [38], respectively. This differential subsidence at the edges of these sebkhas shows the southward declining of the tectonic activity. This decline is also materialized by a more obvious formation of fault-spring mounds [18] along preferential orientations within Sidi El Hani [18], Chrita [21], Boujmal $[19,39]$, and El-Guetiate [20] saline systems. On the other hand, southern saline systems tend to form artesian-spring mounds (e.g., [40]). On the human scale, Bahrouni et al. [32] noticed that the current tectonic activity, which is due to convergence between African and Eurasian plates, affects roads and historical monuments.

\section{Conclusion}

Before and after their real opening and evolution during the post-Villafranchian and the Tyrrhenian tectonics, saline depressions in the Sahel area have been clearly controlled by an inherited geodynamic context. Previous geodynamic events prove vital in the elaboration of a salty context. If the Triassic intrusions and/or evaporates related to the MSC are leached by aquifers converging toward the surface of depressions, they would be the origin of the huge quantities of salt accumulated in sabkhas through groundwater convergence. Accordingly, the water geochemistry is relatively stable and the climatic factor should by rights have been taking a minor role in the filling (water and sediment) of the playa. Currently, the convergence of the plate between African and Eurasian plates results in a tectonic activity within these saline systems materialized by the formation of fault-spring mounds along preferential orientation ensuring the surface-subsurface connectivity. Groundwater upwelling is the agent of transportation of the salty subsurface to the surface. These hydrogeologic and tectonic conditions make a case for inherited saline systems.

\section{Conflict of Interests}

The authors declare that there is no conflict of interests regarding the publication of this paper.

\section{References}

[1] A. Amari and M. Bedir, "Les bassins quaternaires du sahel central de la Tunisie. Genèse et évolution des sebkhas en contexte décrochant compressif et distensif," Géodynamqiue, vol. 4, no. 1, pp. 49-65, 1989.
[2] M. Bedir, Gedynamics of the sedimentary bassin of the Sahel of Mahdia (eastern Tunisia) from the Aptian to the present: sismo-stratigraphy, sismo-tectonic and structural [Ph.D. thesis], University of El Manar Tunis, El Manar, Tunisia, 1989.

[3] S. Khomsi, M. Bédir, and M. G. Ben Jemia, "Mise en évidence d'un nouveau front de chevauchement dans l'Atlas tunisien oriental de Tunisie par sismique réflexion. Contexte structural régional et rôle du Trias salifère," Comptes Rendus Geoscience, vol. 336, pp. 1401-1408, 2004.

[4] S. Khomsi, M. Bédir, M. Soussi, M. G. Ben Jemia, and $\mathrm{K}$. Ben Ismail-Lattrache, "Mise en évidence en subsurface d'événements compressifs Eocène moyen-supérieur en Tunisie orientale (Sahel): généralité de la phase atlasique en Afrique du Nord," Comptes Rendus Geoscience, vol. 338, pp. 41-49, 2006.

[5] H. Gabtni, "Apport de la gravimétrie à l'étude des structures profondes du Sahel de Tunisie (cas de la région de KairouanSousse-Monastir)," Comptes Rendus Geoscience, vol. 337, no. 16, pp. 1409-1414, 2005.

[6] R. Ghribi, Morpho-structural study and evolution of paleo-fields of constraints of the Tunisian Sahel: geodynamic implcations [Ph.D. thesis], Faculty of Sciences of Sfax, Sfax, Tunisia, 2010.

[7] T. Zouaghi, M. Bédir, F. Melki et al., "Neogene sediment deformations and tectonic features of northeastern Tunisia: evidence for paleoseismicity," Arabian Journal of Geosciences, vol. 4, no. 7-8, pp. 1301-1314, 2011.

[8] E. Essefi, Multidisciplinary study of Sidi El Hani Saline environment: the history and the climatic variability [M.S. thesis], Faculty of Sciences of Sfax, University of Sfax, Sfax, Tunisia, 2009.

[9] E. Essefi, J. Touir, M. A. Tagorti et al., "Modeling of the chaotic behavior of Sidi El Hani discharge playa, Tunisian Sahel: which exogenous factor commands this saline environment? The subsurface flow or variability?" in Proceedings of the International Congress Geotunis, 2009.

[10] E. Essefi, J. Touir, M. A. Tagorti, and C. Yaich, "Effect of the groundwater contribution, the climatic change, and the human induced activities on the hydrological behavior of discharge playas: a case study Sidi El Hani discharge playa, Tunisian Sahel," Arabian Journal of Geoscience, vol. 6, no. 10, pp. 39974009, 2013.

[11] M. A. Tagorti, E. Essefi, J. Touir, R. Guellala, and C. Yaich, "Geochemical controls of groundwaters upwelling in saline environments: case study the discharge playa of Sidi El Hani (Sahel, Tunisia)," Journal of African Earth Sciences, vol. 86, pp. $1-9,2013$.

[12] L. Chihi and H. Philip, "Le bloc atlasopélagien: place et évolution géodynamique dans le contexte subduction-collision de la Méditerranée centrale (Afrique du nord-Sicile) du miocène au quaternaire," Notes du Service Géologique de Tunisie, vol. 65, pp. 49-61, 1999.

[13] E. Essefi, G. Komatsu, A. G. Fairén, M. A. Chan, and C. Yaich, "Groundwater influence on the aeolian sequence stratigraphy of the Mechertate-Chrita-Sidi El Hani system, Tunisian Sahel: analogies to the wet-dry aeolian sequence stratigraphy at Meridiani Planum, Terby crater, and Gale crater, Mars," Planetary and Space Science, 2013.

[14] E. Essefi, M. A. Tagorti, J. Touir, and C. Yaich, "Hydrocarbons migration through groundwater convergence toward saline depressions: a case study, Sidi El Hani discharge playa, Tunisian Sahel," ISRN Environmental Chemistry, vol. 2013, Article ID 709190, 14 pages, 2013. 
[15] P. Haller, Structure profonde du Sahel tunisien: interprétation géodynamique [Ph.D. thesis], La Faculté des Sciences et Technologies, Université de Franche-Comté, Paris, France, 1983.

[16] H. Ben Jmaa, The endorheic system of Sidi El Hani, Chrita and Mechertate: paleoenvironment and recent dynamics [Ph.D. thesis], University of Tunis, Tunis, Tunisia, 2008.

[17] E. Essefi, M. A. Tagorti, and J. Touir, "Sensitivity of Sidi El Hani discharge playa to groundwater and climatic variability," in Proceedings of the 22nd Colloquium of African Geology, Hammamet, Tunisia, 2008.

[18] E. Essefi, G. Komatsu, A. G. Fairén, H. Ben Jmaa, F. Rekhiss, and C. Yaich, "Spring mounds at Sidi El Hani saline environment, eastern Tunisia: terrestrial analog for Mars," in Proceedings of the 43rd Lunar and Planetary Science Conference, Houston, Tex, USA, 2012.

[19] E. Essefi, A. G. Fairén, G. Komatsu, F. Rekhiss, and C. Yaich, "Study of cores from a spring mound at the Mars analog of Boujmal, eastern Tunisia: coring martian spring mounds as potential efficient tool for a geologic exploration of early Mars," in Proceedings of the 3rd Conference on Early Mars, Lake Tahoe, Nev, USA, 2012.

[20] E. Essefi, G. Komatsu, A. G. Fairén, M. A. Chan, and C. Yaich, "Alignment of fault spring mounds at El-Guetiate, Southeast Tunisia: terrestrial analogue implications for martian tectonics," in Proceedings of the 44th Lunar and Planetary Science Conference, The Woodlands, Tex, USA, 2013.

[21] E. Essefi, Wet aeolian sedimentology and sequence stratigraphy within the terrestrial analogues of Mechertate-Chrita-Sidi El Hani and Boujmal, eastern Tunisia: implications for wet aeolian sedimentology and sequence stratigraphy on Mars [Ph.D. thesis], National Engineering School of Sfax, University of Sfax, Sfax, Tunisia, 2013

[22] M. Bedir, "Tectonic and basin structuring of eastern Tunisia seismogenic sites," 2010, http://www.docstoc.com.

[23] R. Ghribi, A. Sghari, and S. Bouaziz, "Tectonic evolution of the oriental Tunisian platform from miocene to quaternary," in Proceedings of the 22nd Colloquium of African Geology, Hammamet, Tunisia, 2008.

[24] W. F. Ryan, K. J. Hsü, M. B. Cita et al., Leg 13. Initial Reports of The Deep Sea Drilling Project, vol. 13, US Government Printing Office, Washington, DC, USA, 1973.

[25] K. J. Hsü, M. B. Cita, and W. B. F. Ryan, "The origin of the Mediterranean evaporites," in Reports of the Deep Sea Drilling Project, W. B. F. Ryan and K. J. Hsü, Eds., vol. 13, pp. 1203-1231, US Government Printing Office, Washington, DC, USA, 1973.

[26] S. Duggen, K. Hoernie, P. van den Bogaard, L. Rüpke, and J. P. Morgan, "Deep roots of the Messinian salinity crisis," Nature, vol. 422, no. 6932, pp. 602-606, 2003.

[27] J.-J. Cornée, J.-P. S. Martin, G. Conesa et al., "Correlations and sequence stratigraphic model for Messinian carbonate platforms of the western and central Mediterranean," International Journal of Earth Sciences, vol. 93, no. 4, pp. 621-633, 2004.

[28] W. Krijgsman, F. J. Hilgen, I. Raff, F. J. Sierro, and D. S. Wilson, "Chronology, causes and progression of the Messinian salinity crisis," Nature, vol. 400, no. 6745, pp. 652-655, 1999.

[29] P. Guennoc, C. Gorini, and A. Mauffret, "Histoire géologique du Golfe du Lion et cartographie du rift oligo-aquitanien et de la surface messinienne," Géologie de la France, vol. 3, pp. 67-97, 2000.

[30] A. Sghari and J. L. Mercier, "Le Messinien de la formation "Ségui" du Sahel Tunisien un équivalent des 'Gilbert deltas," in Proceedings of the 22nd Colloquium of African Geology, Hammamet, Tunisia, 2008.

[31] N. El-Euch-El-Kondi, S. Ferry, J. P. Suc, G. Clauzon, and F. Zargouni, "La crise messénienne en Tunisie du nord: réinterprétation des données de Sicile," Communication orale, 2008.

[32] N. Bahrouni, S. Bouaziz, A. Soumaya et al., "Neotectonic and seismotectonic investigation of seismically active regions in Tunisia: a multidisciplinary approach," Journal of Seismology, vol. 18, no. 2, pp. 235-256, 2014.

[33] Y. Kamoun, Etude néotectonique dans la région deMonastirMahdia (Tunisie orientale) [Ph.D. thesis], Université d'Orsay, Paris, France, 1981.

[34] M. Gueddiche, Analysis of sismicity in Tunisia, seismic, seismotectonic and neotectonic study of septentrional Tunisia [Ph.D. thesis], Paris University, Paris, France, 1992.

[35] M. Dlala and S. Rebaï, "Relation compression-extension Miocène supérieur à quaternaire en Tunisie: implication sismotectonique," Comptes Rendus de l'Académie des Sciences, vol. 319, no. 8, pp. 945-950, 1994.

[36] L. Chihi, N. Gaaloul, and S. Razgallah, "Paleoseismic events in Eastern Tunisia (Cap Bon, Sahel): seismites associated with Miocene-Pliocene and quaternary sediments," Africa Geoscience Review, vol. 7, no. 3, pp. 307-314, 2000.

[37] M. A. Tagorti, Rapport d'Étude Bibliographique sur le Secteur de la Sebkha de Sidi El Hani, Annales des Mines et de la Géologie, Tunis, Tunisia, 1995.

[38] L. Marquer, S. Pomel, A. Abichou, E. Schulz, D. Kaniewski, and E. van Campo, "Late Holocene high resolution palaeoclimatic reconstruction inferred from Sebkha Mhabeul, southeast Tunisia," Quaternary Research, vol. 70, no. 2, pp. 240-250, 2008.

[39] E. Essefi, G. Komatsu, A. G. Fairén, F. Rekhiss, and C. Yaich, "Identification of tephra layers in spring mounds at the terrestrial analog of Boujmal, eastern Tunisia: repercussions and limits of tephrostratigraphy application on martian stratigraphy and paleoclimatology," in Proceedings of the 3rd Conference on Early Mars, Lake Tahoe, Nev, USA, 2012.

[40] S. Ferhi, E. Essefi, R. Barbieri, and C. Yaich, "Study of the terrestrial analogue of Chott El Gharsa, southwestern Tunisia: implications for martian study," The 5th Tunisian Days of Applied Geology, 2013.

[41] N. Ben Ayed and F. Zargouni, Carte Sismotectonique de la Tunisie a l'échelle 1/1000 000, Fondation Nationale de la Recherche Scientifique, 1990. 



The Scientific World Journal
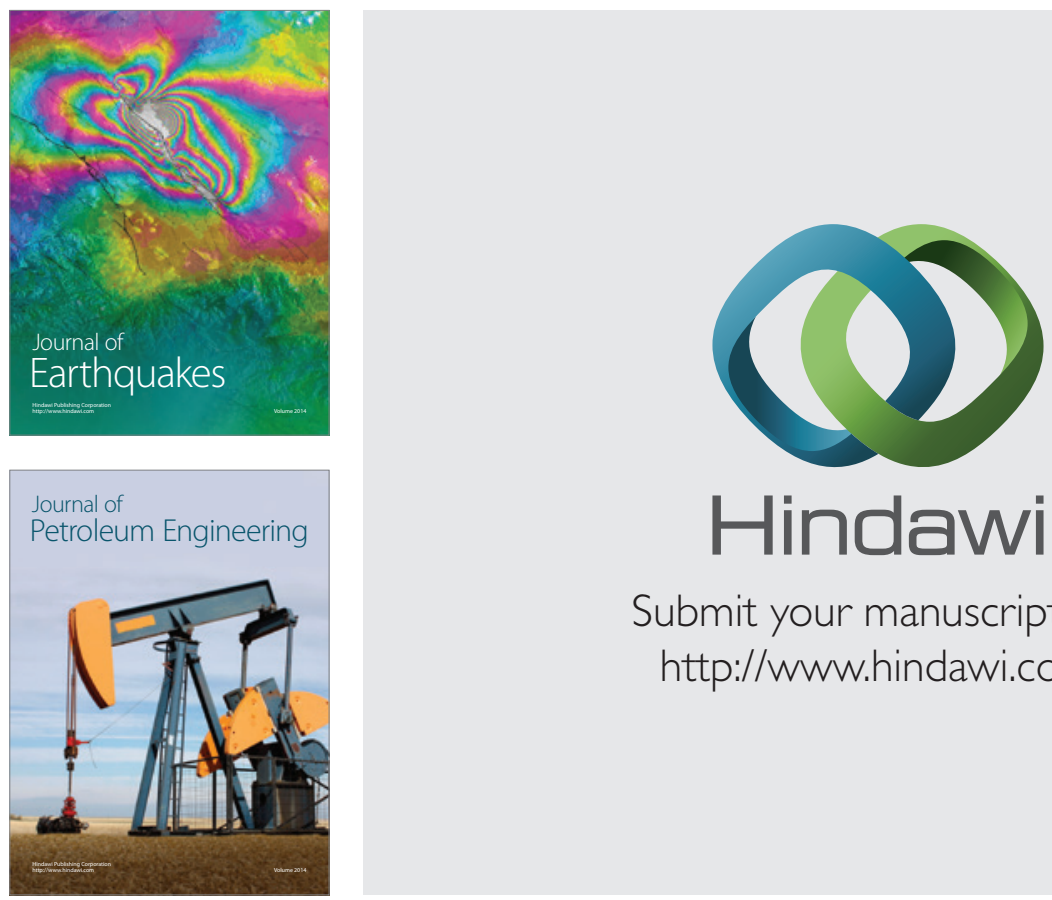

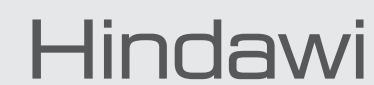

Submit your manuscripts at

http://www.hindawi.com
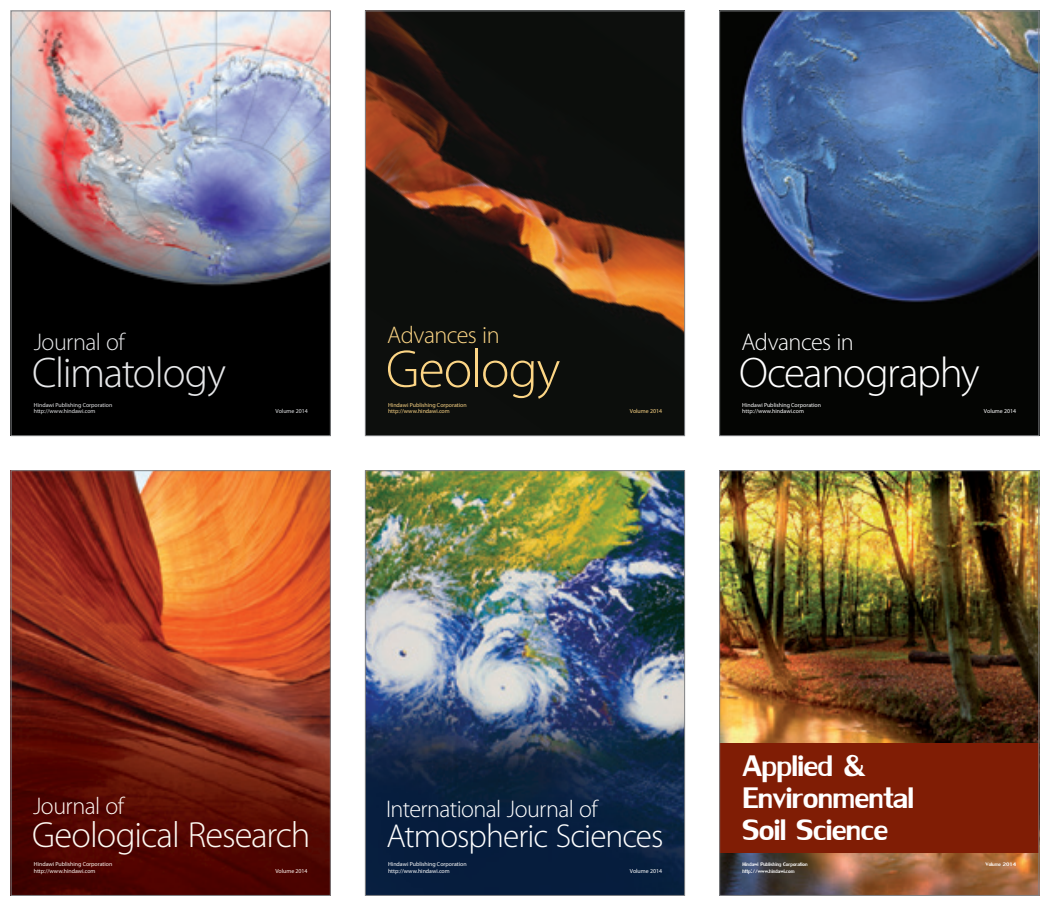
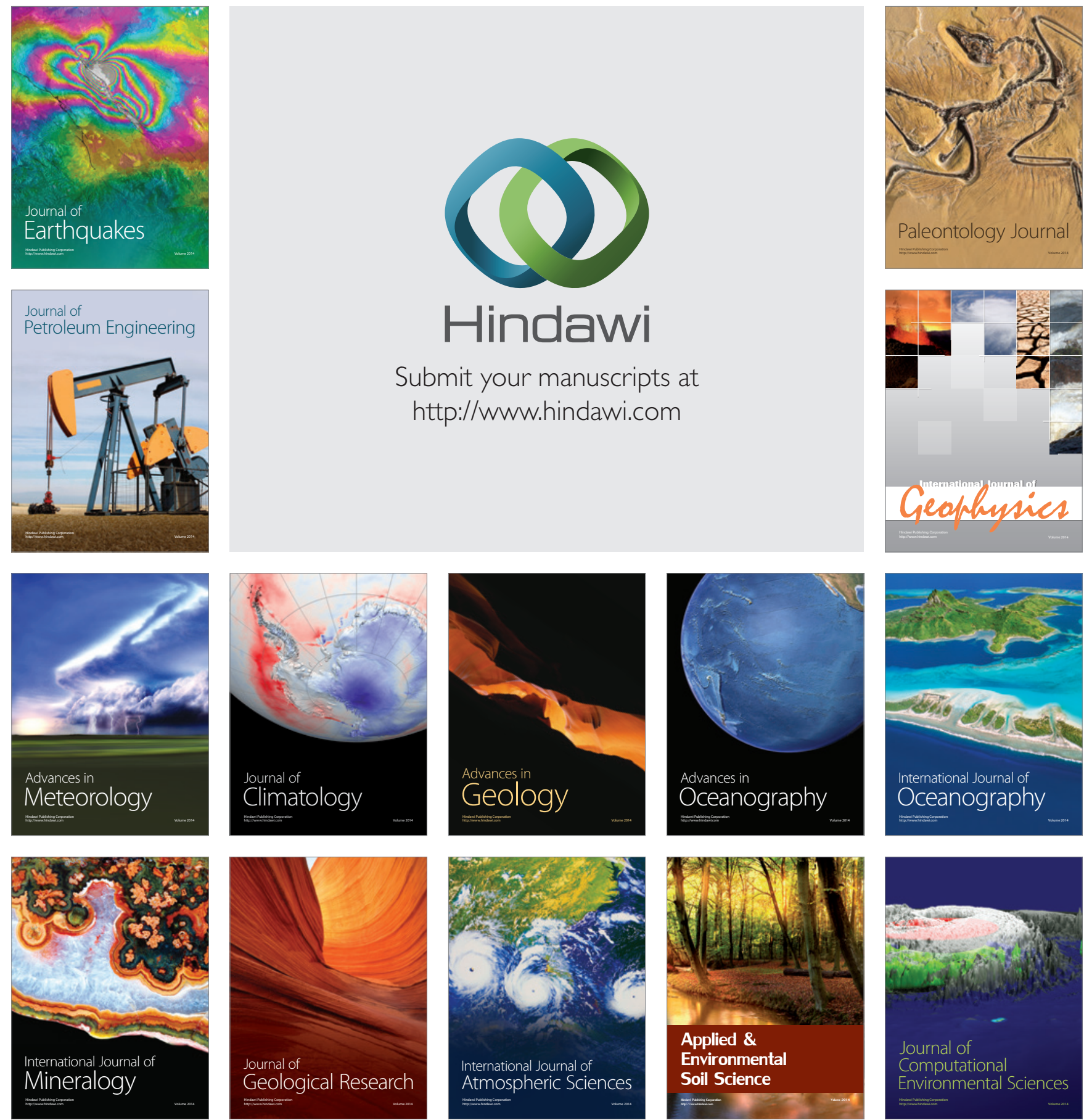